\section{The other side of the Tūhoe raids}

\author{
ALISTAR KATA is contributing editor \\ of Pacific Media Centre's Pacific Media \\ Watch project.
}

The Price of Peace [documentary], directed by Kim Webby. English and Te Reo Māori. 2015, 87min. www.nziff.co.nz/2015/auckland/the-price-of-peace/

$\mathrm{M}$ OST New Zealanders will remember when Tūhoe activist Wairere Tame Iti shot the national flag, during a powhiri ceremony, at a Waitangi Tribunal Hearing in 2005. New Zealanders will also remember when Iti, along with three others, was tried and found guilty of firearms charges as part of what the media coined, the 'Urewera Four' (Gay, 2012) trial. The man with a full facial Tā moko is regarded throughout the mainstream media as somewhat of a rebel, and by the state as a 'dangerous proto-terrorist intent on infecting New Zealand' (Hill, 2012).

But a new documentary, The Price of Peace, by award-winning director and co-producer Kim Webby provides exclusive access to the world of Iti, and gives an alternative approach to the story of the Urewera training camps and the $2007 \mathrm{New}$ Zealand police raids on the Tūhoe community. The film, which made its debut at the New Zealand International Film Festival this year, addressed how the raids specifically affected the Tūhoe community, how the media covered the debacle and the importance of reconciliation and the state of race relations in New Zealand.

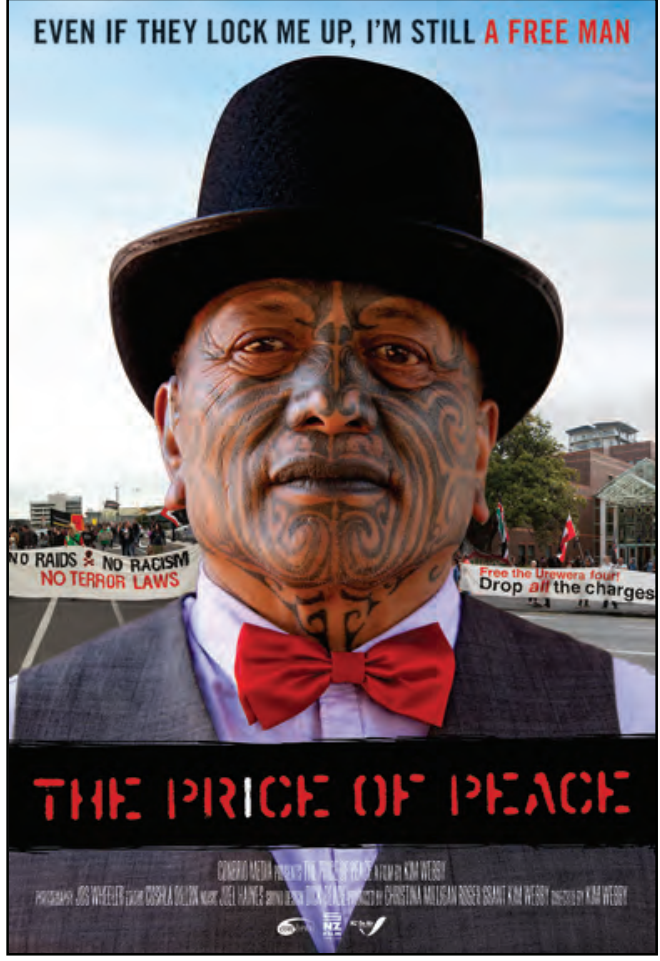

Webby says that it was important to show Iti as more than just an activist. Webby wanted to show the backstory of the way he was raised, the place he was raised and what inspired and sparked him to become an activist. She wanted to show the sides of Iti that the public rarely get to see; the father, grandfather, marae committee member and community leader.

Throughout the film the audience watches him interact with family members and his mokopuna (grandchildren) through his trial, bringing a greater understanding of what kind of person he is away from the spotlight and showing the effect of the trial on the people closest to him.

Secondly, the film confronts the emotional, physical and psychological impact the raids 
had on the Tūhoe community, namely the people of Ruatoki. The emotionally charged testimonies from Iti's partner Maria Steens and her daughter Amie Rangihika give a personal perspective to the situation and show the very real effects of the New Zealand police's actions. Both Steens and Rangihika describe being taken outside their flat, separated from each other and witnessing police hold Iti face down on the ground with guns aimed at his head. In the Sky City cinema on the afternoon of the film's premiere, there was a thick silence and a few sniffles as these very personal stories rolled onto the screen. Webby said the significance of these testimonies was not only to show the traumatic impact of the raids on all involved, but to give an understanding of the legacy they have left on the Ruatoki people, leading into the process of reconciliation.

Thirdly, the documentary focuses on the media's portrayal of Iti as a sensationalised character and reporters branding him as an extreme activist. With a background in journalism, working for shows such as Fair Go and 60 Minutes, Webby understands the nature of news is to always pick the most polarising aspect and for stories to be told in sound bites. But the film provided the opportunity for more in depth coverage of Iti and the Urewera story. One of the most poignant scenes in the film is where Iti emerges from the Auckland High Court and is met with a media scrum. He starts answering their questions in his native tongue and then starts to recite the nursery rhyme 'hey diddle diddle' in Māori, as if to counter the circus that the media had become during the trial.

Through Iti's tale of adversity, the his- tory of race relations in New Zealand is looked at. The documentary shows the reconciliation between Iti's family, the wider Ngāi Tūhoe community and the New Zealand police, represented by Commissioner Mike Bush. These are beautifully spiritual and moving scenes that allow space for a wider dialogue on the misunderstandings and differences between Te Ao Māori (the Māori world) and the Pākehā world. In the film Iti's lawyer, Russell Fairbrother, talks about Iti's trial being a case of two worlds that don't talk easily with each other. $\mathrm{He}$ couldn't have painted a more accurate picture of the history and state of race relations in the country.

Not only is the film Iti's personal story, but his journey represents the struggle of the Ngāi Tūhoe people and their 170-year battle with the state (Joseph, 2015). Towards the end of the film, Webby highlights the significance of the monumental TühoeCrown settlement, which is a fitting way to round out the film and bring closure to the whole story.

There is one element of the film that lends itself to negative critique. The documentary is largely told from a Tūhoe perspective, and unapologetically so. But as a spectator, I found myself thinking back and constantly referencing the coverage I had seen throughout the New Zealand media. I had seen Iti outside the courtroom, I had seen Iti in security footage in the training camps, and like the rest of New Zealand I had seen Iti sitting in the docks of the High Court. The fact of the matter was that I had never seen this side of the story. I had never seen Iti face down on the ground while police were pointing guns at his head, 
I had never seen Steens and her daughter taken from their home by armed officers, and, just like the rest of New Zealand, I had never seen Iti, full-face moko and all, laughing and playing in his backyard with his mokopuna.

What this film calls audiences to do is to understand Māoridom on a deeper level. For the people of Tūhoe, Māori culture isn't something that people are used to seeing just on the marae or whenever the occasion calls for the display of traditional customs, it is a way of life. Tūhoe is a way of life and this film achieves a greater understanding of that notion. It allows the public or audiences to make their own mind up about a man and a community who have previously been misunderstood.

\section{References}

Gay, E. (2012, March 20). Urewera verdict: Crown mulls retrial. The New Zealand Herald. Retrieved from www.nzherald.co.nz/nz/news/ article.cfm?c id $=1$ \&objectid $=10793370$

Hill, M. (2012, March 21). Tame Iti's place in the Maori revolution. Stuff.co.nz. Retrieved from www.stuff.co.nz/national/politics/6608607/ Tame-Itis-place-in-the-Maori-revolution Joseph, J. (2015, May 6). TEDxAuckland 2015: The road less travelled. The New Zealand Herald. Retrieved from www.nzherald. co.nz/element-magazine/news/article.cfm?c id $=1503340 \&$ objectid $=11443982$

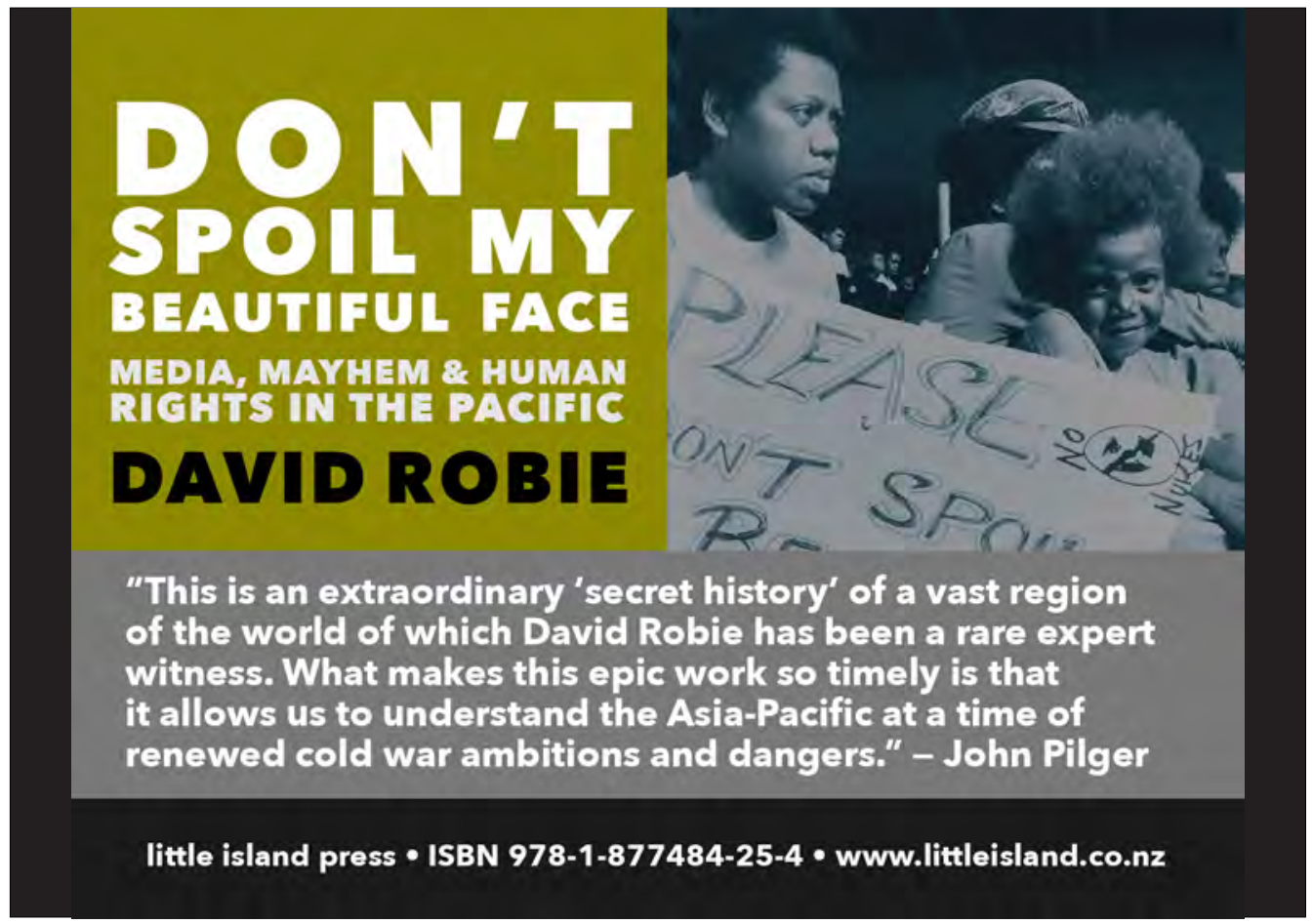

194 PACIFIC JOURNALISM REVIEW 21(1) 2015 